\title{
Aminophosphine Palladium Pincer Complexes for Suzuki and Heck Reactions
}

\author{
Jeanne L. Bolliger and Christian M. Frech*
}

\begin{abstract}
The aminophosphine-based pincer complexes $\left.\left[\mathrm{C}_{6} \mathrm{H}_{3}-2,6-\{\mathrm{NHP} \text { (piperidinyl) })_{2}\right\}_{2} \mathrm{Pd}(\mathrm{Cl})\right]$ (2) and $\left[\mathrm{C}_{6} \mathrm{H}_{3}-\right.$ $\left.2,6-\left\{\mathrm{OP}(\text { piperidiny })_{2}\right\}_{2} \mathrm{Pd}(\mathrm{Cl})\right](\mathbf{3})$ are readily prepared from cheap starting materials by sequential addition of $1,1^{\prime}, 1^{\prime \prime}$-phosphinetriyltripiperidine and 1,3-diaminobenzene or resorcinol to solutions of $\left[\mathrm{Pd}(\operatorname{cod})(\mathrm{Cl})_{2}\right](\mathrm{cod}=\mathrm{cy}$ clooctadiene) in toluene under $\mathrm{N}_{2}$ in 'one pot'. Compounds $\mathbf{2}$ and $\mathbf{3}$ proved to be not only excellent catalysts for the Suzuki and the Heck cross-coupling reactions, but they are also very convenient to use: The toluene solutions of the 'one-pot' syntheses can be used directly for the catalytic reactions, thereby saving the time-consuming isolation of the catalysts. The Suzuki cross-coupling reaction catalyzed by $\mathbf{2}$ and $\mathbf{3}$ can be performed in air at 100 ${ }^{\circ} \mathrm{C}$ in toluene of technical quality: in the presence of only $0.001 \mathrm{~mol} \%$ of catalyst, several electronically deactivated and sterically hindered aryl bromides are quantitatively coupled with phenylboronic acid within a few minutes of reaction time. Furthermore, complex 2 enables the use of activated and non-activated aryl chlorides as coupling partners in the Suzuki reaction. Compounds $\mathbf{2}$ and $\mathbf{3}$ have also been shown to be highly active and reliable Heck catalysts: Very low catalyst loadings and short reaction times are required for the quantitative coupling of several electronically deactivated and sterically hindered aryl bromides with various olefins at $140^{\circ} \mathrm{C}$. At increased temperatures, even electronically deactivated and sterically hindered aryl chlorides can be efficiently coupled with olefins in the presence of only $0.01 \mathrm{~mol} \%$ of catalyst.
\end{abstract}

Keywords: Aminophosphines · C-C coupling · Heck reaction · Pincer complexes · Suzuki reaction

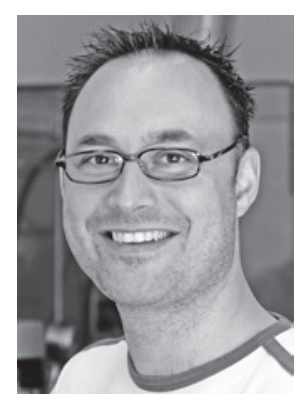

Christian Frech received the diploma in chemistry in 1999 and started his $\mathrm{PhD}$ thesis in the same year at the Institute of Inorganic Chemistry at the University of Zurich with Prof. Dr. H. Berke, where he successfully finished his studies in 2004. Thereafter he joined the research group of Prof. D. Milstein at the Weizmann Institute of Science (Israel) for one year as postdoctoral fellow. Since 2005 he has been working as habilitant at the University of Zurich at the Institute of Inorganic Chemistry at the University of Zurich, working, for example, on the development of new catalysts for $\mathrm{C}-\mathrm{C}$ crosscoupling reactions.

\footnotetext{
${ }^{\star}$ Correspondence: Dr. C. M. Frech

Department für Anorganische Chemie

Universität Zürich

Winterthurerstrasse 190

$\mathrm{CH}-8057$ Zurich

Tel.: + 41446354692

Fax: + 41446356802

E-mail: chfrech@aci.uzh.ch
}

\section{Introduction}

Among the most efficient methods for carbon-carbon bond formation are the palladium-catalyzed Mizoroki-Heck ${ }^{[1]}$ and Suzuki-Miyaura ${ }^{[2,3]}$ cross-coupling reactions, which are nowadays indispensable tools in organic synthesis for the catalytic formation of symmetric and non-symmetric olefins or biaryls, respectively.

Since both of these palladium-catalyzed reactions typically use an aryl halide as one of the starting materials and couple it with either an olefin (Heck reaction) or an arylboronic acid (Suzuki reaction), particularly catalysts which are able to use deactivated and sterically hindered aryl bromides or even aryl chlorides as substrates are of high general interest.

In the last few years, many palladium catalysts for either reaction have been developed, but although some are able to couple sterically or electronically demanding aryl halides at very low catalyst loadings, their syntheses are often not only time consuming and difficult, but also require the use of expensive starting materials. ${ }^{[4-12]}$ Most of these palladium catalysts suffer from other drawbacks as well, such as poor thermal stability as well as poor stability towards oxygen and water, a major problem especially for catalysts employed in the Heck cross-coupling reaction because a typical protocol for this reaction still requires prolonged reaction times at high temperatures in combination with relatively high catalyst loadings - all factors promoting the formation of palladium black and thereby leading to inactivation of the active species.

Pincer complexes of palladium are among the most efficient Heck catalysts and continuously attract attention because of their unique balance between stability and reactivity. Seemingly slight electronic and steric modifications of the pincer core and/or the phosphine substituents have been demonstrated to dramatically influence their catalytic activities. ${ }^{[4 a, d, 13,14]}$ The successful application of pincer-type complexes in the Heck reaction considerably increased the interest in developing pincerbased Suzuki catalysts as well.[15-17] Ever since pincer-type complexes have been successfully introduced as highly efficient catalysts in the Heck reaction, it has been discussed whether a $\mathrm{Pd}^{\mathrm{II}} / \mathrm{Pd}^{\mathrm{IV}}$ mechanism or the formation of palladium nanoparticles leads to their high catalytic activity.[4a,d] Nowadays, pincer complexes are in most cases considered as depot forms of palladium nanoparticles, but nevertheless, the involvement of $\mathrm{Pd}^{\mathrm{IV}}$ intermediates in the catalytic cycle still cannot be excluded completely.[18,19]

Either way, the choice of aminophosphine pincer ligands might prove to be an advantage: Apart from their high $\sigma$-donor strength, aminophosphine ligands can donate additional electron density via the nitrogen lone pairs to the metal center, thereby making $\mathrm{Pd}^{\mathrm{IV}}$ intermediates more 
easily accessible. On the other hand, if palladium nanoparticles are the active species, pincer complexes should act as clean sources of palladium nanoparticles. Since aminophosphines should promote their formation, enhanced catalytic activity as well as shorter induction periods should be observed in comparison with their phosphine and phosphite analogues.

In comparison with many other palladium complexes used to promote the Mizoroki-Heck reaction or the SuzukiMiyaura reaction, the aminophosphinebased palladium pincer complexes $\left[\mathrm{C}_{6} \mathrm{H}_{3}\right.$ 2,6- $\left.\left\{\mathrm{NHP} \text { (piperidinyl) }{ }_{2}\right\}_{2} \mathrm{Pd}(\mathrm{Cl})\right]$ (2) and $\left[\mathrm{C}_{6} \mathrm{H}_{3}-2,6-\left\{\mathrm{OP}\left(\text { piperidinyl) }{ }_{2}\right\}_{2} \mathrm{Pd}(\mathrm{Cl})\right]\right.$ (3) (Scheme 1) are not only readily prepared from cheap starting materials within a day, but they are also extremely efficient catalysts for either reaction: Very low catalyst loadings and short reaction times are required for the quantitative coupling of several electronically deactivated and sterically hindered aryl bromides with phenylboronic acid or various olefins. At increased temperatures, even electronically deactivated and sterically hindered aryl chlorides can be efficiently coupled with olefins in the presence of only $0.01 \mathrm{~mol} \%$ of catalyst. ${ }^{[14,15]}$

Mechanistic studies performed with 2 and $\mathbf{3}$ showed that the Suzuki crosscoupling reaction most probably proceeds via a $\mathrm{Pd}^{\mathrm{II}} / \mathrm{Pd}^{\mathrm{IV}}$ mechanism, ${ }^{[15]}$ while the Heck reaction was shown to be catalyzed by palladium nanoparticles, for which the aminophosphine-based palladium pincer complexes $\mathbf{2}$ and $\mathbf{3}$ apparently are ideal precursors. ${ }^{[14]}$

\section{One-pot Synthesis of the Pincer Complexes}

Instead of synthesizing the pincer ligand separately in a first step and then reacting it with a suitable palladium precursor such as $\left[\mathrm{Pd}(\mathrm{Cl})_{2}(\mathrm{cod})\right](\mathrm{cod}=\mathrm{cy}-$ cloocta-1,5-diene) to the desired complex, aminophosphine-based pincer complexes of palladium with the general formula $\left[\mathrm{Pd}(\mathrm{Cl})\left(\mathrm{C}_{6} \mathrm{H}_{3}-2,6-\mathrm{XP}(\text { piperidinyl })_{2}\right)_{2}\right] \quad(\mathrm{X}$ $=\mathrm{NH}, \mathbf{2}, \mathrm{X}=\mathrm{O}, 3$ ) can be prepared by facile activation of $\mathrm{C}-\mathrm{H}$ and $\mathrm{P}-\mathrm{N}$ bonds. Their syntheses include the use of the readily prepared dichloro(bis $(1,1$ ', 1', (phosphinetriyl)tripiperidine))palladium complex (1) as a template for reactions with 1,3-diaminobenzene or resorcinol to build up the aromatic pincer core directly on the metal center, thus making the independent synthesis and purification of the air- and moisture-sensitive ligand systems unnecessary (Scheme 1).

Treatment of a suspension of $\left[\mathrm{Pd}(\mathrm{Cl})_{2}(\mathrm{cod})\right]$ in toluene under $\mathrm{N}_{2}$ at

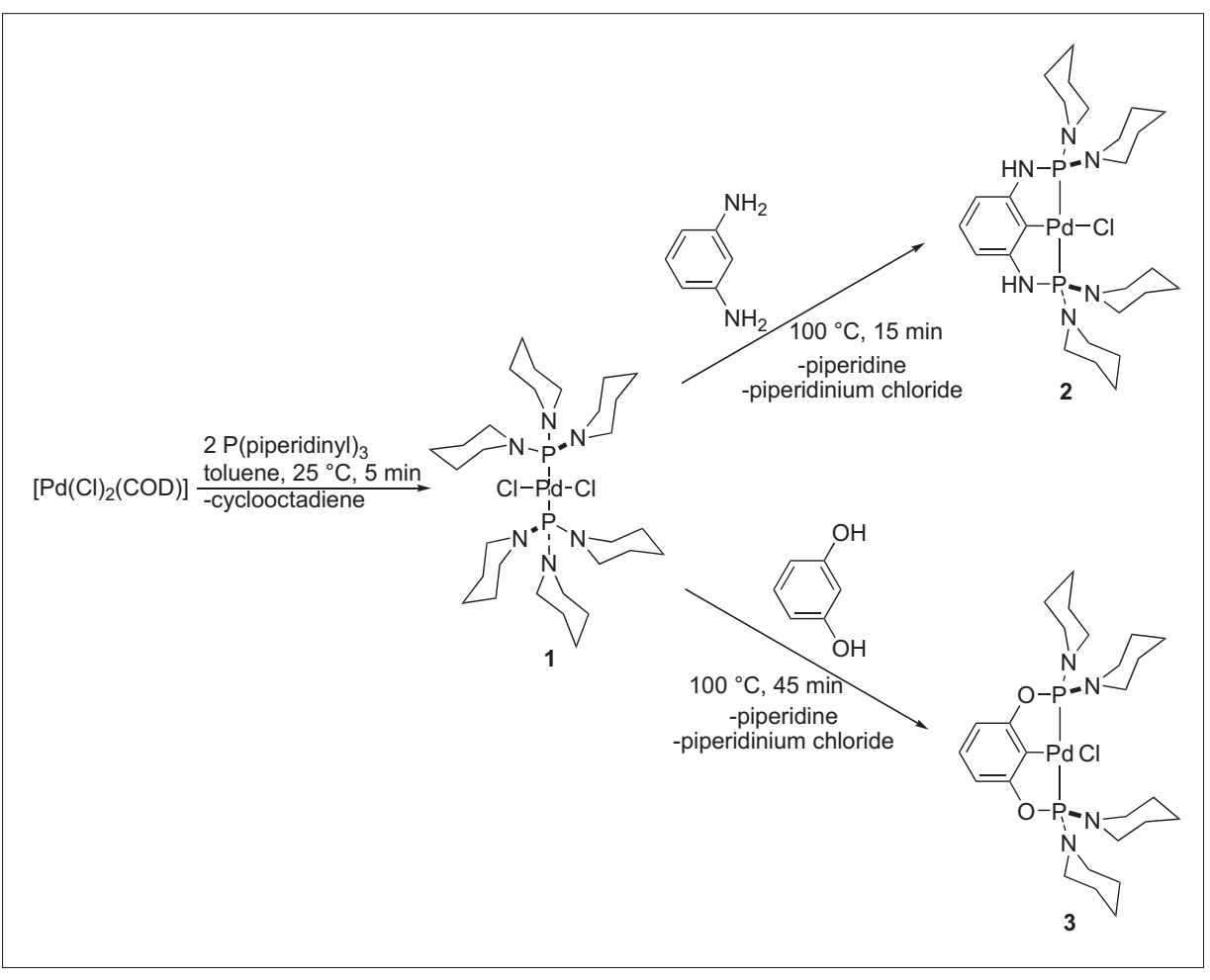

Scheme 1 . Synthesis of the catalysts 2 and 3.

room temperature with two equivalents of $\mathrm{P}$ (piperidinyl) ${ }_{3}$ (which is easily prepared from phosphorus trichloride and piperidine) results immediately in a bright orange solution containing compound $\mathbf{1}$. Addition of an equimolar amount of 1,3-diaminobenzene or resorcinol under nitrogen and stirring at $100{ }^{\circ} \mathrm{C}$ for 15 or $45 \mathrm{~min}$, respectively, leads to the exclusive formation of compounds $\mathbf{2}$ and $\mathbf{3}$. Although removal of the volatiles under reduced pressure and subsequent extractions with diethyl ether gives pure $\mathbf{2}$ and $\mathbf{3}$ in high yields, the isolation of the pincer complexes $\mathbf{2}$ and $\mathbf{3}$ is unnecessary for their application as catalysts in $\mathrm{C}-\mathrm{C}$ cross-coupling reactions. The catalyst solutions of the one-pot syntheses can be used for catalytic reactions without purification and remain stable in solution for several months at room temperature.

Complexes $\mathbf{2}$ and $\mathbf{3}$ are thermally very stable. No visible decomposition was observed upon heating at $150{ }^{\circ} \mathrm{C}$ in NMP or xylene for a week. Toluene solutions of 2 or 3 remain stable at $100{ }^{\circ} \mathrm{C}$ in an oxygen atmosphere for more than a week. On the other hand, addition of a few drops of water to dioxane solutions of $\mathbf{2}$ or $\mathbf{3}$ at 100 ${ }^{\circ} \mathrm{C}$ results in partial palladium deposition after $24 \mathrm{~h}$.

\section{Catalytic Activity of the Pincer Complexes in C-C Cross-Coupling Reactions}

Compounds $\mathbf{2}$ and $\mathbf{3}$ proved to be not only excellent catalysts for the Suzuki-
Miyaura and the Mizoroki-Heck crosscoupling reactions, but they are also very convenient to use: The toluene solutions of the 'one-pot' syntheses can be used directly for the catalytic reactions, thereby saving the time-consuming isolation of the catalysts. The resulting conversion rates and yields in the catalytic reactions are essentially the same as those of freshly prepared catalyst solutions from pure $\mathbf{2}$ and $\mathbf{3}$, respectively.

\subsection{Suzuki Reaction}

Complex 2 turned out to be an extremely efficient catalyst for the Suzuki-Miyaura cross-coupling reaction (Scheme 2) and led to very high reaction rates and yields in extremely short reaction times and with very low catalyst loadings (Table 1). Complex $\mathbf{3}$ generally shows significantly lower catalytic activities than $\mathbf{2}$, but still is among the best catalysts reported up to date. ${ }^{[15]}$

As a consequence of the extremely high catalytic activities of $\mathbf{2}$ and $\mathbf{3}$, the cross-coupling of aryl bromides with phenylboronic acid can be carried out in toluene of technical quality in flasks open to air. This is possible since biaryl formation is much faster than water-induced catalyst degradation.

Best results were obtained at $100{ }^{\circ} \mathrm{C}$ with toluene as solvent with $\mathrm{K}_{3} \mathrm{PO}_{4}$ as base in presence of $0.001 \mathrm{~mol} \%$ of catalyst 2 . Under these conditions, phenylboronic acid was quantitatively coupled with activated, non-activated, and deactivated aryl bromides, such as 4'-bromoacetophenone, bromobenzene, and 4-bromoanisole, 


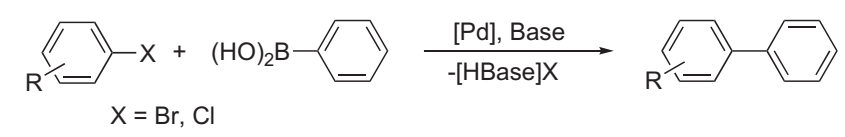

Scheme 2. Suzuki-Miyaura cross-coupling reaction.

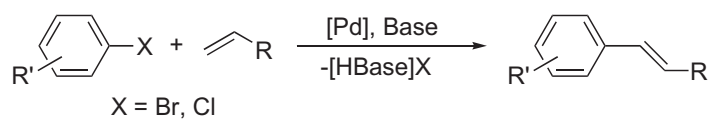

Scheme 3. Mizoroki-Heck cross-coupling reaction. within less than 5 min (Table 1, entries 1, 4 , and 6). Coupling reactions performed with 1,3-dibromobenzene yielded $76 \%$ 1,1':3',1' '-terphenyl and 24\% 3-bromobiphenyl after five minutes, while complete conversion into $1,1^{\prime}: 3^{\prime}, 1^{\prime}$ '-terphenyl was achieved after ten min (Table 1, entry 5). The activity of catalyst $\mathbf{2}$ decreased as sterically hindered substrates were used as coupling partners. While coupling reactions with 2-bromotoluene led to $83 \%$ conversions within $5 \mathrm{~min}, 62 \%$ conversion was obtained after 15 min using 2-bromo$m$-xylene as the substrate (Table 1 , entries 8 and 9). Similar conversions but longer reaction times were observed when catalyst $\mathbf{3}$ was used in place of catalyst $\mathbf{2}$ for the $\mathrm{C}-\mathrm{C}$ coupling of phenylboronic acid with bromobenzene, 4-bromoanisole, or 3-bromo- $m$-xylene (Table 1 , entries 3 and 7).

Reactions carried out with 4'- chloroacetophenone or chlorobenzene also showed high conversion rates in short reaction times (Table 1, entries 11-13). For example, complete conversions of chlorobenzene at $100{ }^{\circ} \mathrm{C}$ with $0.1 \mathrm{~mol} \%$ catalyst 2 was observed after 90 min (Table 1, entry 11). In contrast, coupling reactions with deactivated or sterically hindered aryl chlorides were less successful and only led to approximately $10 \%$ conversions after 3 h (Table 1 , entries 14 and 15).

Nevertheless, in most of the examples of the Suzuki-Miyaura cross-coupling reactions performed (in particular when aryl bromides as well as activated and unactivated aryl chlorides were employed), catalysts $\mathbf{2}$ (and to a minor extent $\mathbf{3}$ ) were more efficient than the reference systems of $\left[\mathrm{Pd}(\mathrm{Cl})\left(\mathrm{C}_{6} \mathrm{H}_{3}\left(\mathrm{NHP}(\mathrm{Ph})_{2}\right)_{2}\right],{ }^{[17]}\right.$ $\left.\left[\mathrm{Pd}_{2}(\mathrm{Cl})_{2}\left(\mathrm{C}_{6} \mathrm{H}_{2}(\mathrm{tBu})_{2} \mathrm{O}\right) \mathrm{P}(\mathrm{OR})_{2}\right)_{2}\right],{ }^{[11 \mathrm{~g}, \mathrm{hl}]}$ and $\mathrm{Pd}(\mathrm{OAc})_{2} / \mathrm{PCy}_{2} \mathrm{Ar}^{[3 \mathrm{~h}]}$ Comparisons with the extremely active air- and moisturestable NHC-bearing $\left[\mathrm{Pd}^{\mathrm{II}}(\mathrm{Cl})(\mathrm{R}\right.$-allyl) $(\mathrm{NHC}=\mathrm{N} \text {-heterocyclic carbene })^{[20]}$ complexes are difficult, since the Suzuki reactions were generally performed at room temperature.[12k] However, because of the

Table 1. Suzuki cross-coupling reaction of aryl halides with phenylboronic acid catalyzed by $\left[\mathrm{Pd}(\mathrm{Cl})\left(\mathrm{C}_{6} \mathrm{H}_{3}-2,6-\left(\mathrm{YP}(\text { piperidinyl })_{2}\right)_{2}\right](\mathrm{Y}=\mathrm{NH}, \mathbf{2} ; \mathrm{Y}=\mathrm{O}, \mathbf{3})^{\mathrm{a}}\right.$

\begin{tabular}{|c|c|c|c|c|c|c|}
\hline Entry & Aryl halide & $\begin{array}{l}\text { Catalyst } \\
([\mathrm{mol} \%])\end{array}$ & $\begin{array}{l}\text { Conv. } \\
{[\%]^{b}}\end{array}$ & $t[\mathrm{~min}]$ & TOF $^{\mathrm{c}}$ & $\mathrm{TON}^{\mathrm{d}}$ \\
\hline 1 & bromobenzene & $2(0.001)$ & 100 & 5 & 1'200'000 & $100 ’ 000$ \\
\hline 2 & bromobenzene & $2(0.0001)$ & 100 & 55 & 1'090'909 & 1'000'000 \\
\hline 3 & bromobenzene & $3(0.001)$ & 98 & 10 & $558 ' 000$ & $294^{\prime} 000$ \\
\hline 4 & 4'-bromoacetophenone & $2(0.001)$ & 100 & 4 & 1'500'000 & $100 ’ 000$ \\
\hline 5 & 1,3-dibromobenzene & $2(0.001)$ & 100 & 10 & $600 ’ 000$ & $50 ’ 000$ \\
\hline 6 & 4-bromoanisole & $2(0.001)$ & 95 & 5 & 1'140'000 & $95^{\prime} 000$ \\
\hline 7 & 4-bromoanisole & $3(0.001)$ & 96 & 10 & $5766^{\prime} 000$ & $966^{\prime} 000$ \\
\hline 8 & 2-bromotoluene & $2(0.001)$ & 83 & 5 & 996’000 & 83’000 \\
\hline 9 & 2-bromo-m-xylene & $2(0.001)$ & 62 & 15 & $248^{\prime} 000$ & $62 ' 000$ \\
\hline 10 & 2-bromo-m-xylene & $3(0.001)$ & 92 & 30 & $184^{\prime} 000$ & 92’000 \\
\hline 11 & chlorobenzene & $2(0.1)$ & 99 & 90 & 653 & 980 \\
\hline 12 & chlorobenzene & $3(0.1)$ & 31 & 90 & 207 & 276 \\
\hline 13 & 4'-chloroacetophenone & $2(0.01)$ & 92 & 90 & $6{ }^{\prime} 133$ & 9'200 \\
\hline 14 & 2-chloro-m-xylene & $2(0.1)$ & 11 & 180 & 37 & 110 \\
\hline 15 & 4-chloroanisole & $2(0.1)$ & 8 & 180 & 27 & 80 \\
\hline
\end{tabular}

aReaction conditions: $4.0 \mathrm{mmol}$ aryl halide, $6.0 \mathrm{mmol} \mathrm{PhB}(\mathrm{OH})_{2}, 8.0 \mathrm{mmol} \mathrm{K} \mathrm{PO}_{4}, 12 \mathrm{ml}$ toluene (technical quality), catalyst (synthesized in 'one-pot' and used without purification) added in solution, reactions performed in air at $100^{\circ} \mathrm{C}$. ' Determined by GC/MS, based on aryl halide. ${ }^{\mathrm{c}}$ Defined as mol product per mol of catalyst per hour. ${ }^{\mathrm{d}}$ Defined as mol product per mol of catalyst. high conversions obtained within a few minutes and the facile syntheses of $\mathbf{2}$ and $\mathbf{3}$, these systems belong to the most convenient Suzuki catalysts reported to date.

The Suzuki reaction is strongly influenced by the choice of the solvent and base, as well as the reaction temperature. For example, replacing toluene by NMP and/or $\mathrm{K}_{3} \mathrm{PO}_{4}$ by $\mathrm{K}_{2} \mathrm{CO}_{3}$ or $\mathrm{Cs}_{2} \mathrm{CO}_{3}$ led to a substantial drop in the reaction rate. Similarly, lowering the reaction temperature to $50{ }^{\circ} \mathrm{C}$ led to only $30 \%$ conversion after 12 $\mathrm{h}$ and $58 \%$ conversion after $24 \mathrm{~h}$ with 0.01 mol\% of catalyst 2 while almost no activity was observed at room temperature.

\subsection{Heck Reaction}

The aminophosphine-based palladium pincer complexes $\left[\mathrm{C}_{6} \mathrm{H}_{3}-2,6\right.$ $\left\{\mathrm{NHP}(\text { piperidinyl) }\}_{2} \mathrm{Pd}(\mathrm{Cl})\right] \quad$ (2) and $\left[\mathrm{C}_{6} \mathrm{H}_{3}-2,6-\left\{\mathrm{OP}\left(\text { piperidinyl) }{ }_{2}\right\}_{2} \mathrm{Pd}(\mathrm{Cl})\right]\right.$ (3) are also extremely efficient and reliable Heck catalysts (Scheme 3). ${ }^{[14]}$

Very low catalyst loadings and short reaction times are required for the quantitative coupling of several electronically deactivated and sterically hindered aryl bromides with various olefins (Table 2). At increased temperatures, even electronically deactivated and sterically hindered aryl chlorides can be efficiently coupled with olefins in the presence of only $0.01 \mathrm{~mol} \%$ of catalyst (Table 3 ).

As in the Suzuki cross-coupling, catalyst $\mathbf{3}$ is generally less active than $\mathbf{2}$ in Heck reactions performed with aryl bromides. For example, styrene and bromobenzene underwent complete $\mathrm{C}-\mathrm{C}$ coupling in the presence of only $0.002 \mathrm{~mol} \%$ of 2 and $\mathrm{K}_{2} \mathrm{CO}_{3}$ within $2.5 \mathrm{~h}$ in DMF at $140{ }^{\circ} \mathrm{C}$, whereas a reaction time of $10 \mathrm{~h}$ was necessary with catalyst 3 (Table 2, entries 1 and 2). As demonstrated by the cross-coupling of styrene with the electronically deactivated 4-bromoanisole or the sterically hindered 2-bromotoluene, as well as the reaction of 4-methoxystyrene or 2-methylstyrene with bromobenzene, catalyst 2 offers two possible pathways to the same products, which are obtained in high yields and short reaction times by either way (Table 2, entries 5-9). Although a decrease in activity was observed with 2-bromo- $m$ xylene and styrene as substrates, nevertheless $95 \%$ conversion was obtained after 8 h (Table 2, entry 10). Heck reactions performed with N,N-dimethyl acrylam- 
Table 2. Heck cross-coupling reaction of aryl bromides with various olefins catalyzed by $\left[\mathrm{Pd}(\mathrm{Cl})\left(\mathrm{C}_{6} \mathrm{H}_{3}-2,6-\left(\mathrm{YP}(\text { piperidinyl })_{2}\right)_{2}\right](\mathrm{Y}=\mathrm{NH}, \mathbf{2} ; \mathrm{Y}=\mathrm{O}, \mathbf{3})^{\mathrm{a}}\right.$

\begin{tabular}{|c|c|c|c|c|c|c|c|}
\hline Entry & Aryl halide & Olefin & $\begin{array}{l}\text { Cat. } \\
\text { (ppm) }\end{array}$ & $\begin{array}{l}\text { Conv. [\%] } \\
\text { (cis/trans/gem) }\end{array}$ & $t[\mathrm{~h}]$ & TOF $^{\mathrm{c}}$ & $\mathrm{TON}^{\mathrm{d}}$ \\
\hline 1 & bromobenzene & styrene & $2(20)$ & $>99(1 / 90 / 10)$ & 2.5 & $19 ’ 880$ & $49^{\prime} 700$ \\
\hline 2 & bromobenzene & styrene & $3(20)$ & $96(1 / 90 / 10)$ & 10 & 4’800 & $48^{\prime} 000$ \\
\hline $3^{e}$ & bromobenzene & styrene & $2(0.2)$ & $>99(1 / 90 / 10)$ & 36 & 138 '333 & 4'980'000 \\
\hline 4 & 1,3-dibromobenzene & styrene & $2(20)$ & $>99(1 / 7 / 0 / 0)^{\dagger}$ & 3.5 & $14 ' 157$ & $49^{\prime} 550$ \\
\hline 5 & 4-bromoanisole & styrene & $2(20)$ & $99(0 / 10 / 1)$ & 2.5 & $199^{\prime} 800$ & $49^{\prime} 500$ \\
\hline 6 & bromobenzene & 4-methoxystyrene & $2(20)$ & $97(0 / 10 / 1)$ & 2.5 & $19^{\prime} 400$ & $48 ’ 500$ \\
\hline 7 & 4-bromoanisole & styrene & $3(20)$ & $97(0 / 10 / 1)$ & 11 & 4’409 & $48 ’ 500$ \\
\hline 8 & 2-bromotoluene & styrene & $2(20)$ & $98(0 / 20 / 1)$ & 2.5 & $19 ' 600$ & $49^{\prime} 000$ \\
\hline 9 & bromobenzene & 2-methylstyrene & $2(20)$ & $90(0 / 20 / 1)$ & 2.5 & $18^{\prime} 000$ & $45^{\prime} 000$ \\
\hline $10^{g}$ & 2-bromo-m-xylene & styrene & $2(20)$ & $95(2 / 80 / 1)$ & 8 & $2 ' 375$ & $19^{\prime} 000$ \\
\hline 11 & bromobenzene & $\mathrm{N}, \mathrm{N}$-dimethyl acrylamide & $2(20)$ & $100(1 / 20 / 0)$ & 2 & $25^{\prime} 000$ & $50 ’ 000$ \\
\hline 12 & bromobenzene & $\mathrm{N}, \mathrm{N}$-dimethyl acrylamide & $3(20)$ & $100(1 / 25 / 0)$ & 10 & $5 ’ 000$ & $50 ’ 000$ \\
\hline 13 & 2-bromotoluene & $\mathrm{N}, \mathrm{N}$-dimethyl acrylamide & $2(20)$ & $100(1 / 40 / 0)$ & 4 & $12^{\prime} 500$ & $50 ’ 000$ \\
\hline 14 & bromobenzene & $n$-butyl acrylate & $2(50)$ & $100(1 / 100 / 1)$ & 4.5 & $4 ’ 444$ & $20 ’ 000$ \\
\hline 15 & bromobenzene & $n$-butyl acrylate & $3(50)$ & $93(1 / 100 / 0)$ & 12 & 775 & 9'300 \\
\hline 16 & 4-bromoanisole & $n$-butyl acrylate & $2(50)$ & $99(1 / 100 / 0)$ & 4.5 & 4 '400 & $19 ’ 800$ \\
\hline 17 & bromobenzene & $n$-butyl vinyl ether & $2(50)$ & $100(4 / 3 / 2)$ & 5 & 4’000 & $20 \prime 000$ \\
\hline 18 & bromobenzene & $n$-butyl vinyl ether & $3(50)$ & $99(4 / 3 / 2)$ & 16 & $1 ’ 238$ & $199^{\prime} 800$ \\
\hline $19^{9}$ & 2-bromo-m-xylene & $n$-butyl vinyl ether & $2(50)$ & $72(5 / 3 / 5)$ & 8 & $1 ' 800$ & $14{ }^{\prime} 400$ \\
\hline $20^{g}$ & bromobenzene & 4-vinylpyridine & $2(200)$ & $100(1 / 25 / 0)$ & 8.5 & 589 & $5 ’ 000$ \\
\hline $21^{g}$ & 2-bromotoluene & 4-vinylpyridine & $2(200)$ & $100(1 / 20 / 0)$ & 12 & 417 & $5 ’ 000$ \\
\hline $22^{g}$ & bromobenzene & 2-vinylpyridine & $2(200)$ & $53(1 / 10 / 0)$ & 60 & 44 & $2^{\prime} 650$ \\
\hline $23^{h}$ & bromobenzene & $(E)$-stilbene & $2(50)$ & 98 & 20 & 980 & 19 '600 \\
\hline $24^{h}$ & bromobenzene & 1,1-diphenylethene & $2(50)$ & 99 & 24 & 825 & $19^{\prime} 800$ \\
\hline
\end{tabular}

aReaction conditions: $4.0 \mathrm{mmol}$ aryl halide, $4.4 \mathrm{mmol}$ olefin, $4.4 \mathrm{mmol} \mathrm{K}_{2} \mathrm{CO}_{3}, 5 \mathrm{ml} \mathrm{DMF}$, catalyst (synthesized in 'one pot' and used without

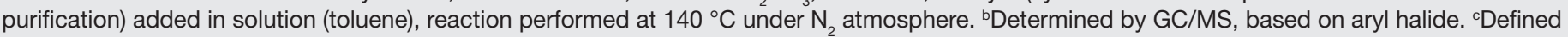
as mol product per mol of catalyst per hour. ${ }^{d}$ Defined as mol product per mol of catalyst. e $2.0 \mathrm{~mol}$ aryl halide, $2.4 \mathrm{~mol}$ olefin, $2.4 \mathrm{~mol} \mathrm{~K}_{2} \mathrm{CO}_{3}, 1$ I DMF. fProduct distribution refers to (cis-trans/trans-trans/gem-trans/cis-cis). ${ }^{~}$ Reactions performed in NMP. ${ }^{h}$ Reaction performed at $160{ }^{\circ} \mathrm{C}$.

Table 3. Heck cross-coupling reaction of aryl chlorides with various olefins catalyzed by $\left[\mathrm{Pd}(\mathrm{Cl})\left(\mathrm{C}_{6} \mathrm{H}_{3}-2,6-\left(\mathrm{YP}(\text { piperidinyl })_{2}\right)_{2}\right](\mathrm{Y}=\mathrm{NH}, \mathbf{2} ; \mathrm{Y}=\mathrm{O}, \mathbf{3})^{\mathrm{a}}\right.$

\begin{tabular}{|c|c|c|c|c|c|c|c|}
\hline Entry & Aryl halide & Olefin & Cat. & $\begin{array}{l}\text { Conv. [\%] }{ }^{\mathrm{b}} \\
\text { (cis/trans/gem) }\end{array}$ & $t[\mathrm{~h}]$ & $\mathrm{TOF}^{\mathrm{c}}$ & $\mathrm{TON}^{\mathrm{d}}$ \\
\hline $1^{e}$ & 4'-chloroacetophenone & styrene & 2 & $100(5 / 100 / 1)$ & 2.5 & 4000 & 10000 \\
\hline $2^{e}$ & 4'-chloroacetophenone & styrene & 3 & $95(0 / 1 / 0)$ & 2.5 & 3800 & 9500 \\
\hline $3^{e}$ & 4'-chloroacetophenone & $\mathrm{N}, \mathrm{N}$-dimethyl acrylamide & 2 & $99(0 / 1 / 0)$ & 2.5 & 3960 & 9900 \\
\hline $4^{e}$ & 4'-chloroacetophenone & $\mathrm{N}, \mathrm{N}$-dimethyl acrylamide & 3 & $96(0 / 20 / 1)$ & 2.5 & 3840 & 9600 \\
\hline 5 & chlorobenzene & $\mathrm{N}, \mathrm{N}$-dimethyl acrylamide & 2 & $77(3 / 100 / 1)$ & 16 & 481 & 7700 \\
\hline 6 & chlorobenzene & $\mathrm{N}, \mathrm{N}$-dimethyl acrylamide & 3 & $91(0 / 60 / 1)$ & 16 & 569 & 9100 \\
\hline 7 & 2-chloro-m-xylene & $\mathrm{N}, \mathrm{N}$-dimethyl acrylamide & 2 & $57(0 / 1 / 0)$ & 28 & 204 & 5700 \\
\hline 8 & 4-chloroanisole & $\mathrm{N}, \mathrm{N}$-dimethyl acrylamide & 2 & $66(0 / 1 / 0)$ & 72 & 92 & 6600 \\
\hline 9 & chlorobenzene & 4-methylstyrene & 2 & $82(1 / 80 / 10)$ & 12 & 683 & 8200 \\
\hline 10 & 4-chlorotoluene & 4-methylstyrene & 2 & $80(1 / 7 / 0)$ & 18 & 444 & 8000 \\
\hline 11 & chlorobenzene & 4-methoxystyrene & 2 & $90(1 / 100 / 10)$ & 18 & 500 & 9000 \\
\hline 12 & chlorobenzene & 4-methoxystyrene & 3 & $100(1 / 100 / 10)$ & 18 & 556 & 10000 \\
\hline 13 & 4-chlorotoluene & 4-methoxystyrene & 3 & $98(0 / 8 / 1)$ & 18 & 544 & 9800 \\
\hline
\end{tabular}

aReaction conditions: $4.0 \mathrm{mmol}$ aryl halide, $6.0 \mathrm{mmol}$ olefin, $4.4 \mathrm{mmol} \mathrm{K}_{2} \mathrm{CO}_{3}, 0.6 \mathrm{mmol}$ tetrabutylammonium bromide, $5 \mathrm{ml} \mathrm{NMP,} 0.01 \mathrm{~mol} \%$ of catalyst (synthesized in one pot and used without purification) added in solution (toluene), reaction performed at $200{ }^{\circ} \mathrm{C}$ under $\mathrm{N}_{2}$ atmosphere. ${ }^{b}$ Determined by GC/MS, based on aryl halide. 'Defined as mol product per mol of catalyst per hour. ${ }^{\mathrm{d}}$ Defined as mol product per mol of catalyst. eReaction performed at $160^{\circ} \mathrm{C}$. 
ide exhibit very similar conversion rates and yields to those with styrene (Table 2, entries 11-13). Complete product formation and excellent selectivities but slightly lower conversion rates were observed with n-butyl acrylate as coupling partner (Table 2, entries 14-16). For instance, using deactivated 4-bromoanisole as substrate led to quantitative $(97 \%)$ product formation within $4.5 \mathrm{~h}$ in the presence of only 0.005 mol\% of 2. Quantitative product formation but a further decrease in the conversion rates accompanied by low selectivity was observed after $5 \mathrm{~h}$ with $0.005 \mathrm{~mol} \%$ of 2 with the electronically deactivated n-butyl vinyl ether (Table 2, entries 17-18). Even the sterically hindered 2-bromo- $m$-xylene was converted to $72 \%$ of product after only $8 \mathrm{~h}$ (Table 2, entry 19). When the amount of catalyst was increased to $0.02 \mathrm{~mol} \%$, 4-vinylpyridine for example undergoes quantitative coupling with bromobenzene and the sterically hindered 2-bromotoluene within 8 and $12 \mathrm{~h}$ (Table 2, entries 20 and 21). Significantly lower conversion rates were observed with 2-vinylpyridine (Table 2, entry 22), most probably due to chelation.

Furthermore, the exceptional high catalytic activity of $\mathbf{2}$ and its practical applicability was demonstrated in an exemplary 'large-scale' reaction, in which bromobenzene $(210 \mathrm{ml} ; 2.0 \mathrm{~mol})$ and styrene $(250$ $\mathrm{ml} ; 2.4 \mathrm{~mol}$ ) were quantitatively coupled in the presence of only $0.00002 \mathrm{~mol} \%$ of catalyst within $36 \mathrm{~h}$ (Table 2, entry 3 ).

Additionally, raising the reaction temperature to $160{ }^{\circ} \mathrm{C}$ allows the use of disubstituted olefins, such as $(E)$-stilbene or 1,1-diphenylethene as coupling partners. For instance, 1,1',1' '-ethene-1,1,2-triyltribenzene was quantitatively formed within $20 \mathrm{~h}$ on addition of 1.1 equivalents of bromobenzene to solutions of $(E)$-stilbene in DMF (Table 2, entry 23). Notably, the same product was formed quantitatively within $24 \mathrm{~h}$ under identical reaction conditions by either using 1,1-diphenylethene as substrate (Table 2, entry 24), or by adding 2.2 equivalents of bromobenzene to solutions of styrene in DMF.

In contrast to Heck reactions performed with aryl bromides, catalysts $\mathbf{2}$ and $\mathbf{3}$ show the same level of activity with aryl chlorides as substrates. In the presence of 0.01 mol\% of catalyst and about $15 \%$ of tetrabutylammonium bromide in 1-methyl-2-pyrrolidone (NMP) at $160{ }^{\circ} \mathrm{C}$, the electronically activated 4'-chloroacetophenone and $\mathrm{N}, \mathrm{N}$-dimethyl acrylamide or styrene were coupled almost quantitatively within $2.5 \mathrm{~h}$ (Table 3, entries 1-4). Increasing the reaction temperature to $200{ }^{\circ} \mathrm{C}$, enabled even the coupling of nonactivated, deactivated, and ortho-substituted aryl chlorides with various olefins. For example, reactions performed with chlorobenzene and N,N- dimethyl acrylamide afforded the coupling product in $77 \%$ yield in the presence of catalyst 2 and in $91 \%$ yield with catalyst 3 after 16 h (Table 3, entries 5 and 6). Remarkably, even the sterically hindered 2-chloro- $m$-xylene was converted to about $60 \%$ of the product after $28 \mathrm{~h}$ in the presence of $\mathbf{2}$ with N,N-dimethyl acrylamide as coupling partner (Table 3, entry 7). A prolonged reaction time was required with the electronically deactivated 4-chloroanisole as substrate (Table 3, entry 8). A conversion of $82 \%$ was achieved within 12 $\mathrm{h}$ when chlorobenzene was coupled with 4-methylstyrene (Table 3, entry 9). Even higher conversions were observed after 18 $\mathrm{h}$ when chlorobenzene or 4-chlorotoluene were allowed to react with 4-methylstyrene or 4-methoxystyrene as coupling partners (Table 3, entries 10-13).

Overall, $\mathbf{2}$ and $\mathbf{3}$ belong to the most active and most convenient Heck catalysts reported up to date, since their catalyst solutions are readily prepared from very cheap starting materials in 'one pot' and can be used directly for catalytic reactions without purification. Catalyst $\mathbf{2}$ (and to a minor degree $\mathbf{3}$ ) are more efficient in the majority of the coupling reactions performed with aryl bromides than many systems reported in literature. ${ }^{[4 a, 13 a, 21-23]}$ although in some cases comparisons are difficult, since the Heck reactions were generally carried out at room temperature. ${ }^{[5,6]}$ Likewise, because of the wide span of reaction temperatures employed, the Heck reactions performed with aryl chlorides are nearly impossible to compare with other systems. ${ }^{[4 \mathrm{~d}, 5 \mathrm{~b}, 24]}$

\section{Conclusions}

In summary, a new concept for the short, facile and high yielding synthesis of complexes with the general formula $[\mathrm{Pd}(\mathrm{Cl})$ $\left(\mathrm{C}_{6} \mathrm{H}_{3}-2,6-\left(\mathrm{YP}(\text { piperidinyl })_{2}\right)_{2}\right](\mathrm{Y}=\mathrm{NH}$, 2; or $\mathrm{Y}=\mathrm{O}, \mathbf{3})$ has been developed. ${ }^{[15]}$ Compounds $\mathbf{2}$ and $\mathbf{3}$ proved to be not only excellent catalysts for the Suzuki-Miyaura and the Mizoroki-Heck cross-coupling reactions, but they are also very convenient to use: The toluene solutions of the 'onepot' syntheses can be used directly for the catalytic reactions, thereby saving the time-consuming isolation of the catalysts.

Due to the high catalytic activity of 2 (and to a minor extent 3 ), the Suzuki reaction performed with aryl bromides can be carried out in toluene of technical quality in a flask open to air since biaryl formation is much faster than water-induced catalyst degradation. ${ }^{[15]}$

Compounds $\mathbf{2}$ and $\mathbf{3}$ have also been shown to be highly active and reliable Heck catalysts: Very low catalyst loadings and short reaction times are required for the quantitative coupling of several electronically deactivated and sterically hindered aryl bromides with various olefins at $140{ }^{\circ} \mathrm{C}$. At increased temperatures, electronically deactivated and sterically hindered aryl chlorides can be efficiently coupled with olefins in the presence of only $0.01 \mathrm{~mol} \%$ of catalyst. ${ }^{[14]}$ Further catalytic reactions performed with complexes $\mathbf{2}$ and $\mathbf{3}$ are in progress.

\section{Acknowledgement}

This research was supported by the University of Zurich and the Swiss National Science Foundation (SNSF).

Received: January 9, 2009

[1] R. F. Heck, H. A. Dieck, J. Am. Chem. Soc. 1974, 96, 1133.

[2] N. Miyaura, K. Yamada, A. Suzuki, Tetrahedron Lett. 1979, 20, 3437.

[3] a) N. Miyaura, A. Suzuki, Chem. Rev. 1995, 95 , 2457; b) A. Suzuki in 'Metal-Catalyzed CrossCoupling Reactions', Eds. F. Diederich, P. J. Stang, Wiley-VCH, Weinheim, 1998, chap. 2; c) A. Suzuki, J. Organomet. Chem. 1999, 576, 147; d) N. Miyaura, Top. Curr. Chem. 2002, 219, 11; e) J. Hassan, M. Sevignon, C. Gozzi, E. Schulz, M. Lemaire, Chem. Rev. 2002, 102, 1359; f) S. Kotha, K. Lahiri, D. Kashinath, Tetrahedron 2002, 58, 9633; g) F. Bellina, A. Carpita, R. Rossi, Synthesis 2004, 2419; h) T. E. Barder, S. D. Walker, J. R. Martinelli, S. L. Buchwald, J. Am. Chem. Soc. 2005, 127, 4685.

[4] a) M. Ohff, A. Ohff, M. E. van der Boom, D. Milstein, J. Am. Chem. Soc. 1997, 119, 11687 ; b) K. Kiewel, Y. Liu, D. E. Bergbreiter, G. A. Sulikowski, Tetrahedron Lett. 1999, 40, 8945; c) F. Miyazaki, K. Yamaguchi, M. Shibasaki, Tetrahedron Lett. 1999, 40, 7379; d) D. MoralesMorales, R. Redon, C. Yung, C. M. Jensen, Chem. Commun. 2000, 1619; e) D. MoralesMorales, C. Grause, K. Kasaoka, R. Redon, R. Cramer, C. M. Jensen, Inorg. Chim. Acta 2000, 300-302, 958; f) S. Sjovall, O. P. Wendt, C. J. Anderson, Chem. Soc. Dalton Trans. 2002, 1396; g) D. Morales-Morales, R. E. Cramer, C. M. Jensen, J. Organomet. Chem. 2002, 654, 44; h) M. R. Eberhard, Org. Lett. 2004, 2125; i) N. Withcombe, K. K. Hii, S. Gibson, Tetrahedron 2001, 57, 7449 .

[5] a) W. A. Herrmann, C. Brossmer, K. Öfele, C. Reisinger, T. Riermeier, M. Beller, H. Fisher, Angew. Chem. 1995, 107, 1989; Angew. Chem., Int. Ed. Engl. 1995, 34, 1844; b) A. Littke, G. C. Fu, J. Org. Chem. 1999, 64, 10; c) X. Gai, R. Grigg, I. Ramzan, V. Sridharan, S. Collard, J. Muir, Chem. Commun. 2000, 2053; d) S. Gibson, D. Foster, D. Eastham, R. Tooze, D. Cole-Hamilton, Chem. Commun. 2001, 779; e) M. Albrecht, G. van Koten, Angew. Chem. 2001, 113, 3866; Angew. Chem. Int. Ed. 2001, 40, 3750; f) M. E. van der Boom, D. Milstein, Chem. Rev. 2003, 103, 1759.

[6] A. F. Littke, G. C. Fu, J. Am. Chem. Soc. 2001 123, 6989

[7] J. P. Stambuli, S. R. Stauffer, K. H. Shaughnessy, J. F. Hartwig, J. Am. Chem. Soc. 2001, 123, 2677.

[8] a) S. Y. Cho, M. Shibasaki, Tetrahedron: Asymmetry 1998, 9, 3751; b) A. N. Cammidge, K. V. L. Crépy, Chem. Commun. 2000, 1723; c) J. Yin, S. L. Buchwald, J. Am. Chem. Soc. 2000 , 122, 12051; d) A. S. Castanet, F. Colobert, P. E. Broutin, M. Obringer, Tetrahedron: Asymmetry 2002, 13, 659; e) A. Herrbach, A. Marinetti, O. Baudoin, D. Guenard, F. Gueritte, J. Org Chem. 2003, 68, 4897; f) A. N. Cammidge, K. 
V. L. Crépy, Tetrahedron 2004, 60, 4377; g) K. Mikami, T. Miyamoto, M. Hatano, Chem. Commun. 2004, 2082.

[9] a) G. Altenhoff, R. Goddard, C. W. Lehmann, F. Glorius, J. Am. Chem. Soc. 2004, 126, 15195; b) S. D. Walker, T. E. Barder, J. R. Martinelli, S. L. Buchwald, Angew. Chem. 2004, 116, 1907 ; Angew. Chem., Int. Ed. 2004, 43, 1871; c) T. E. Barder, S. D. Walker, J. R. Martinelli, S. L. Buchwald, J. Am. Chem. Soc. 2005, 127, 4685.

[10] For a review on Pd-catalyzed coupling reactions of aryl chlorides, see A. F. Littke, G. C. Fu, Angew. Chem. 2002, 114, 4350; Angew. Chem., Int. Ed. 2002, 41, 4176.

[11] a) J. P. Wolfe, R. A. Singer, B. H. Yang, S. L. Buchwald, J. Am. Chem. Soc. 1999, 121, 9550; b) A. Zapf, A. Ehrentraut, M. Beller, Angew. Chem. 2000, 112, 4315; Angew. Chem., Int. Ed. 2000, 39, 4153; c) D. A. Alonso, C. Najera, M. C. Pacheco, J. Org. Chem. 2002, 67, 5588; d) R. B. Bedford, C. S. J. Cazin, S. L. Hazelwood, Angew. Chem. 2002, 114, 4294; Angew. Chem., Int. Ed. 2002, 41, 4120; e) R. B. Bedford, S. L. Hazelwood, M. E. Limmert, Chem. Commun. 2002, 2610; f) R. B. Bedford, S. L. Hazelwood, M. E. Limmert, D. A. Albisson, S. M. Draper, P. N. Scully, S. J. Coles, M. B. Hursthouse, Chem. Eur. J. 2003, 9, 3216; g) R. B. Bedford, S. L. Hazelwood, P. N. Horton, M. B. Hursthouse, Dalton Trans. 2003, 4164; h) D. A. Albisson, R. B. Bedford, S. E. Lawrence, P. N. Scully, Chem. Commun. 1998, 2095.

[12] a) D. W. Old, J. P. Wolfe, S. L. Buchwald, J. Am. Chem. Soc. 1998, 120, 9722; b) D. Zim, A. S. Gruber, G. Ebeling, J. Dupont, A. L. Monteiro, Org. Lett. 2000, 2, 2881; c) M. R. Netherton, C. Dai, K. Neuschutz, G. C. Fu, J. Am. Chem. Soc. 2001, 123, 10099; d) T. J. Colacot, E. S. Gore, A. Kuber, Organometallics 2002, 21, 3301; e) J. H. Kirchhoff, M. R. Netherton, I. D. Hills, G. C. Fu, J. Am. Chem. Soc. 2002, 124,
13662 ; f) C.W. K. Gstöttmayr, V. P. W. Böhm, E. Herdtweck, M. Grosche, W. A. Herrmann, Angew. Chem. 2002, 114, 1421; Angew. Chem., Int. Ed. 2002, 41, 1363; g) Q.-S. Hu, Y. Lu, Z.-Y. Tang, H.-B. Yu, J. Am. Chem. Soc. 2003 125, 2856; h) G. Altenhoff, R. Goddard, C. W. Lehmann, F. Glorius, Angew. Chem. 2003, 115, 3818; Angew. Chem., Int. Ed. 2003, 42, 3690; i) O. Navarro, R. A. Kelly, S. P. Nolan, J. Am. Chem. Soc. 2003, 125, 16194; j) F. Y. Kwong, K. S. Chan, C. H. Yeung, A. S. C. Chan, Chem. Commun. 2004, 2336; k) N. Marion, O. Mei, E. D. Stevens, N. M. Scott, S. P. Nolan, J. Am. Chem. Soc. 2006, 128, 4101.

[13] a) E. Peris, J. A. Loch, J. Mata, R. H. Crabtree, Chem. Commun. 2001, 201; b) S. Gründemann, M. Albrecht, J. A. Loch, J. W. Faller, R. H. Crabtree, Organometallics 2001, 20, 5485; c) J. A. Loch, M. Albrecht, E. Peris, J. Mata, J. W. Faller, R. H. Crabtree, Organometallics 2002, 21, 700; d) D. J. Nielsen, K. J. Cavell, B. W. Skelton, A. H. White, Inorg. Chim. Acta 2002, 327, 116; e) W. A. Herrmann, V. P. W. Böhm, C. W. K. Gstöttmayr, M. Grosche, C.-P. Reisinger, T. Weskamp, J. Organomet. Chem. 2001, 617, 616; f) C. Yang, H. M. Lee, S. P. Nolan, Org. Lett. 2001, 3, 1511; g) N. Tsoureas, A. A. Danopoulos, A. A. D. Tulloch, M. E. Light, Organometallics 2003, 22, 4750 .

[14] J. L. Bolliger, O. Blacque, C. M. Frech, Chem. Eur. J. 2008, 14, 7969

[15] J. L. Bolliger, O. Blacque, C. M. Frech, Angew. Chem., Int. Ed. 2007, 46, 6514.

[16] J. T. Singleton, Tetrahedron 2003, 59, 1837.

[17] D. Benito-Garagorri, V. Bocokic, K. Mereiter, K. Kirchner, Organometallics 2006, 25, 3817.

[18] Reviews that include catalysis of the Heck reaction by palladacycles: a) see refs [4a,b]; b) P. L. Beletskaya, A. V. Cheprakov, Chem. Rev. 2000, 100, 3009; c) M. Dupont, M. Pfeffer, J. Spencer, Eur. J. Inorg. Chem. 2001, 1917; d)
R. B. Bedford, Chem. Commun. 2003, 1787; e) G. J. de Vries, Dalton Trans. 2006, 421; f) D. E. Bergbreiter, P. L. Osburn, J. D. Frels, Adv. Synth. Catal. 2005, 347, 172; g) K. Yu, W. Sommer, J. M. Richardson, M. Weck, C. W. Jones, Adv. Synth. Catal. 2005, 347, 161; h) K. Yu, W. Sommer, M. Weck, C. W. Jones, J. Catal. 2005, 226, 101.

[19] a) W. A. Herrmann, V. P. W. Böhm, C.-P. Reisinger, J. Organomet. Chem. 1999, 576, 23; b) B. L. Shaw, S. D. Perera, E. A. Staley, Chem. Commun. 1998, 1362.

[20] a) A. J. Arduengo, H. V. Rasika Dias, R. L. Harlow, M. Kine, J. Am. Chem. Soc. 1992, 114, 5530; b) M. S. Viciu, R. M. Kissling, E. D. Stevens, S. P. Nolan, Org. Lett. 2002, 4, 2229; c) O. Navarro, R. A. Kelly, S. P. Nolan, J. Am. Chem. Soc. 2003, 125, 16194; d) M. S. Viciu, R. A. Kelly, E. D. Stevens, F. Naud, M. Studer, S. P. Nolan, Org. Lett. 2003, 5, 1479.

[21] H. M. Lee, J. Y. Zeng, C.-H. Hu, M.-T. Lee, Inorg. Chem. 2004, 43, 6822.

[22] A. H. M. de Vries, J. M. C. A. Mulders, J. H. M. Mommers, H. J. W. Henderickx, J. G. de Vries, Org. Lett. 2003, 5, 3285.

[23] a) W. A. Herrmann, M. Elison, J. Fischer, C. Köcher, G. R. J. Artus, Angew. Chem. 1995, 107, 2602; Angew. Chem., Int. Ed. 1995, 34, 2371; b) G. D. Frey, C. Reisinger, E. Herdtweck, W. A. Herrmann, J. Organomet. Chem. 2005, 690,3193 ; c) W. A. Herrmann, K. Öfele, S. K. Schneider, E. Herdtweck, S. D. Hoffmann, Angew. Chem. 2006, 118, 3943; Angew. Chem., Int. Ed. 2006, 45, 3859 .

[24] A. Schnyder, T. Aemmer, A. F. Indolese, U. Pittelkow, M. Studer, Adv. Synth. Catal. 2002. $344,495$. 